\title{
AMAZING ANTIMICROBIAL AND WOUND HEALING POTENTIAL OF ACACIA CATECHU BARK EXTRACTS- A REVIEW
}

\author{
ARCHANA TIWARI ${ }^{1 *}$, AVINASH TIWARI ${ }^{2}$ \\ ${ }^{1}$ Assistant Professor Department of Botany, Government P.G. College, Damoh, Madhya Pradesh, India. ${ }^{2}$ Department of Microbiology, \\ School of Studies in Microbiology, Jiwaji University, Gwalior, Madhya Pradesh, India. Email: archanaashish19@gmail.com
}

Received: 15 July 2021, Revised and Accepted: 10 September 2021

\section{ABSTRACT}

Plants are not only the source of food, oxygen, and shelter, but the same are also a potential foundation of medicines. Many natural and plant-derived antimicrobial and wound healing compounds have been recognized. In the present review, we have studied the main bioactive components of Acacia catechu with their medicinal roles. Most of these bioactive components are secondary metabolites which are produced by plants as side products of certain physiological reactions and are of no use for the plant itself. These components have been reported for their medicinal properties. In this review, we have mentioned some antibacterial, antifungal, and wound healing properties of A. catechu with its known bioactive components. The aim of this review article is, to enlist the possible potent bioactive components of the plant, against pathogenic microbes that can replace the use of chemicals and synthetic antibiotics for the treatment of skin infections and other diseases.

Keywords: Acacia catechu, Bioactive compounds, Antimicrobial activity, Synthetic antibiotics, Wound healing, Secondary metabolites.

(C) 2021 The Authors. Published by Innovare Academic Sciences Pvt Ltd. This is an open access article under the CC BY license (http://creativecommons.org/ licenses/by/4.0/) DOI: http://dx.doi.org/10.22159/ajpcr.2021v14i10.43009. Journal homepage: https://innovareacademics.in/journals/index.php/ajpcr

\section{INTRODUCTION}

Over long ago both humans and animal are depend on plants for food and also for their primary health care. In all over the world, more than $30 \%$ of the plant species are in use for medicinal purposes [1]. Recent data revealed that more than Rs. 20,00,000 million/annum is spent in the world market for plant-derived drugs. Though India is rich in vegetation and medicinal plants, but the Indian contribution for the same is less than Rs. 20,000 million/year [2,3]. India has great diversity and origin of many crops and medicinal plants. In India, the importance of medicinal plants has already been highlighted by several workers [3-5]

During the searching of available literature on antimicrobial plants and their extracts we have found many treatments based on plant-derived oil, extract, fine powder, etc. In addition to this, the data also revealed that from the $19^{\text {th }}$ sanctuary to $21^{\text {st }}$ sanctuary the use of these natural products is increased to double $[4,6]$. Many numbers and categories of plant-based antimicrobial and anti-infectious compounds have been recognized. More common of them are essential oils, alkaloids, flavonoids, sesqui-terpene lactones and naphtoquinones, etc [5,7-9]. The same has documented for wound healing activity of different parts of plant extracts with or without their mechanism of action [8,10-14].

In this section we have focused on antimicrobial and wound healing activities of Acacia catechu wild bark extracts. A. catechu Wild is one of the remarkable medicinal plants having immense medicinal potential in almost all parts of its body [15]. From long it has been widely using in Ayurveda and other medical systems for many diseases, both as an external and oral ingredient [16,17]. A. catechu is abundantly spread throughout the greater part of India due to its more adaptability in different atmospheric conditions, though in the desert and most humid areas limited varieties are reported [15-18]. In India, the most common varieties seen are A. catechu namely, Catechu, Catechuoides, and Sundra. From which, the Catechu variety is most commonly used to obtain Katha $[18,19]$. Some common names of this plant in different languages are "black catechu" in English, "Kher" in Gujarati, "Khayera" in Bengali, "Katha" in Hindi, "Kachinamara" in Kannada, "Kath" in Kashmiri, "Kharira" in Assamese, "Karingali" in Malayalam, "Kharira in Marathi" "Kaviri" in Urdu, "Chanbe" in Telugu etc $[17,19]$.
Already the different parts of the same has been reported to be effective against skin diseases, melancholia, conjunctivits, diabetes, haemaptysis, hepato-protective activity, catarrah, cough, pruritus, leprosy, body surface infection, leucoderma, colon diseases, helminthiasis, norexia, diarrhea, dysentery, foul ulcers and wound treatment, hemorrhages, fever, anemia, and pharyngodynia [16,18-20]. Because of such vast medicinal values, the same is widely used in various drug formulations too. A. catechu also known as Katha in Hindi which is a dispensable ingredient of pan (betel leaf preparation) chewed in India and other countries $[19,21]$.

It is useful pan due to its capability to cure throat infections and dental problems [20]. This plant is also known for its various pharmacological effects like anti-inflammatory, antioxidative, antipyretic, anticancer, anti-ulcer, etc [20-22]. In this review, we have mentioned the antimicrobial and wound healing activities of this plant with special reference to its bark extracts. Here, we have also mentioned the studied bio-active components associated with the above-given activities with their mechanism of action. For basic understanding, a brief classification of plants with its morphology has also been given here.

\section{MORPHOLOGY OF A. CATECHU PLANT}

A. catechu wild is a medium to the higher-sized deciduous tree. Its stem is usually straight in the beginning and becomes branched after attending a certain height. The stems are usually brown to grayish in color with think bark [17]. This plant has bipinnately compound, small leaves with 2-6 $\mathrm{mm}$ length and arrange in pairs of pinnae. These leaves are supported by a glandular rachis in pairs. Inland areas the plant showed cylindrical inflorescence in the winter season with axillary pedunculate spike $[17,19,20]$. Its flowers are actinomorphic to zygomorphic, 5-10 cm long, sessile, pentamerous, which exhibit creamy whitish to pale yellow color with a $1-1.5 \mathrm{~mm}$ long campanulate calyx. The corolla is normally $2.5-3 \mathrm{~mm}$ long. Stamens are abundant in number and arrange in the far exerted form from the corolla [22]. These are white to yellowish-white filaments, having bisexual configuration and with single superior carpel; pod is one chambered legume, glabrous oblong, 3-10 seeded, straight, flat and brown with a triangular beak at the apex, shiny, narrowed at the base [21,23-25]. 


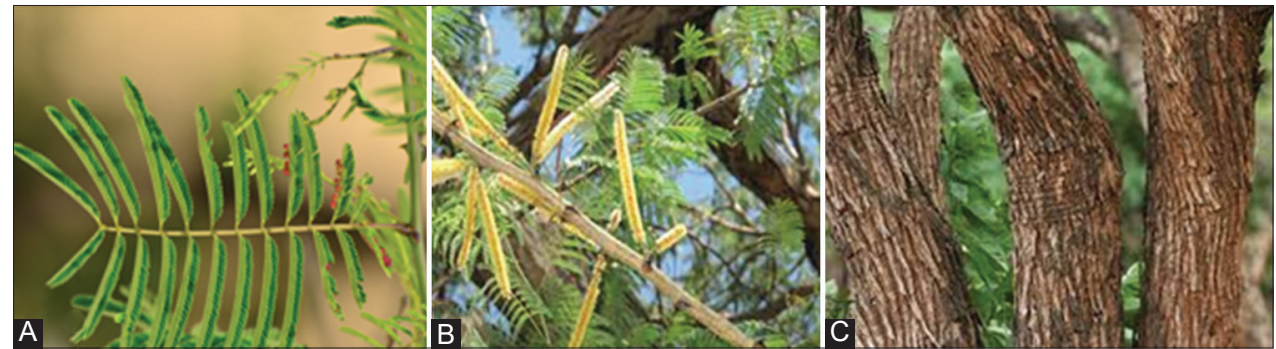

Fig. 1: (A) Leaves, (B) Inflorescence, (C) Stem and bark of Acacia catechu plant<smiles>O=C(O)c1cc(O)c(O)c(O)c1</smiles>

(A) Gallic acid<smiles>O=C1c2c(O)cc(O)cc2O[C@H](c2ccc(O)c(O)c2)C1O</smiles>

(C) Taxifolin<smiles>Oc1cc(O)c2c(c1)O[C@H](c1ccc(O)c(O)c1)C(O)C2</smiles>

(B) Catechin<smiles>Oc1ccc([C@@H]2Oc3cc(O)cc(O)c3C[C@H]2O)cc1</smiles>

(D) Afzelchin

Fig. 2: Chemical structures of (A) Gallic acid, (B) Catechin, (C) Taxifolin, (D) Afzelchin<smiles>O=c1cc(-c2ccc(O)c(O)c2)oc2cc(O)cc(O)c12</smiles>

(E) Quercetin<smiles>O=C(OC1Cc2c(O)cc(O)cc2OC1c1ccc(O)c(O)c1)c1cc(O)c(O)c(O)c1</smiles>

(G) Epicatechin gallate<smiles>CC1OC(Oc2c(-c3ccc(O)c(O)c3)oc3cc(O)cc(O)c3c2=O)C(O)C(O)[C@H]1O</smiles>

(F) Quercitrin

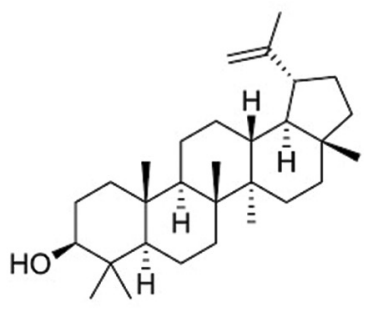

(H) Lupeol

Fig. 3: Chemical Structures of (E) Quercetin, (F) Quercitrin, (G) Epicatechin gallate, $(\mathrm{H})$ Lupeol

\section{ANTIMICROBIAL ACTIVITIES OF A. CATECHU BARK}

In vitro studies of A. catechu wild are reported to have a broad spectrum anti-microbial and anti-fungal activity $[23,26]$. In the last decade, a

Table 1: Classification of $A$. catechu

\begin{tabular}{ll}
\hline Kingdom & Plantae \\
\hline Division & Magnoliophyta \\
Class & Magnoliopsida \\
Subclass & Rosidae \\
Order & Fabales \\
Family & Fabaceae \\
Genus & Acacia Mill. \\
Species & A. catechu wild - Black cutch \\
\hline
\end{tabular}

A. catechu: Acacia catechu

number studied have put data on the antibacterial activity of Acacia bark extract against some specific and some multi-drug resistant disease-causing bacteria [27-29]. Some recent scientific studies have revealed the antibacterial activity of different extracts of the heartwood of A. catechu and reported strong antibacterial and antifungal activities in different experimental models. In few in-vitro evaluations too, the same is found to be exhibiting the antibacterial activity against enteric pathogens [30,31]. In species-specific anti-bacterial assays both ethanolic and aqueous extracts of the heartwood of $A$. catechu were seen to be successfully effective against Salmonella typhi, Shigella flexneri, Escherichia coli, Klebsiella pneumonia, Vibrio cholera, Pseudomonas aeruginosa and Staphylococcus aureus, etc bacterial cells [32-34]. In the same, the ethanolic extract was observed to be more efficient than the aqueous extract of the same also more efficient than the standard used $[27,29,32]$. Though, molecular level studies on the anti-microbial action of given bark extract is meager. But in few in-vitro antimicrobial assays the same; the phytochemical analysis showed that the alkaloids and carbohydrate substances are major bioactive compound work against pathogenic bacterial cells [33-35]. In one other research methanolic extract of $A$. catechu bark reported for its toxic effects against Bacillus subtilis, S. aureus, S. typhi, E. coli, P. aeruginosa and Candida albicans species of microorganisms [36]. To find out the responsible components of organic plant's extracts were separated by thin layer chromatography (TLC) and plant extracts were purified by column chromatography and were identified by Gas chromatography-mass spectrometry analysis. The analysis confirmed the presence of terpene, for example, camphor (nearly 76\%) and phytol (nearly 28\%) that to relate with its antibacterial and antifungal properties [28,32,36,37].

Phytochemical investigation of $A$. catechu wild shows the presence of alkaloids, flavonoids, glycosides, carbohydrates, phenolic compounds, different types of terpenes, saponins, steroids, and tannins which may be responsible for its anti-microbial activity. Methanolic extract of A. catechu wild (bark) has been known for antibacterial efficacy against both Gram-positive and Gram-negative bacteria. The same has also found to be helpful against $S$. aureus infection [22,25,30,34,38-40].

\section{WOUND HEALING ACTIVITIES OF A. CATECHU}

Wounds are actually disrupted by cellular or histological structures associated with loss of integrity and function. Though nature has given each living being the auto-power of regeneration, but sometimes severe damage in tissues and/or infection with some pathogen may cause deadly consequences [41]. In such cases, treatment with an anti- microbial agent 
Table 2: The different categories, bioactive compounds and their medicinal properties are listed below

\begin{tabular}{|c|c|c|c|c|}
\hline S. No. & $\begin{array}{l}\text { Category of } \\
\text { Phyto-chemical }\end{array}$ & Bioactive compounds & $\begin{array}{l}\text { Related medicinal } \\
\text { activities }\end{array}$ & References \\
\hline 1. & Flavanoids & $\begin{array}{l}\text { Catechin, Epigallocatechin, Epicatechin } \\
\text { gallate, Epicatechin, Epigallocatechin gallate, } \\
\text { Eocatechin, Catecutannic acid, Quercetin, } \\
\text { Quercitrin, Phloroglucinol, Procatechuic } \\
\text { lupenone, Lupeol, Procyanidin AC Quercitrin } \\
\text { acid, etc. }\end{array}$ & $\begin{array}{l}\text { Antioxidative, } \\
\text { Anti-inflammatory, } \\
\text { Antipyretic, Anticancer, } \\
\text { Anti-ulcer, Skin } \\
\text { diseases, Melancholia, } \\
\text { Conjunctivits, Diabetes, } \\
\text { Hepato-protective } \\
\text { activity, Cough, Pruritus, } \\
\text { Leprosy, Body surface } \\
\text { infection, Dysentery, Foul } \\
\text { Ulcers Wound treatment, } \\
\text { Haemorrages, Anaemia, } \\
\text { Pharyngodynia }\end{array}$ & {$[16,30,44,48,64-49,71,72]$} \\
\hline 2. & Alkaloids & $\begin{array}{l}\text { Taxifolin dihydrokaempferol, Kaempferol, } \\
\text { Afzelchin gum, etc. }\end{array}$ & $\begin{array}{l}\text { Antioxidative, } \\
\text { Anti-inflammatory, } \\
\text { Diabetes, Haemaptysis, } \\
\text { Hepato-protective } \\
\text { activity, Catarrah, } \\
\text { Body surface infection, } \\
\text { Leucoderma, Colon } \\
\text { diseases, Diarrhea, } \\
\text { Dysentery, Wound } \\
\text { treatment, Anaemia, } \\
\text { Pharyngodynia }\end{array}$ & {$[18,36,40-47,53-55,73,74]$} \\
\hline 3. & Glycosides & $\begin{array}{l}\text { Poriferasterol, Poriferasterol acylglucosides } \\
\text { etc. }\end{array}$ & $\begin{array}{l}\text { Antioxidative, } \\
\text { Anti-inflammatory, } \\
\text { Antipyretic, Anticancer, } \\
\text { Anti-ulcer, Skin } \\
\text { diseases, Melancholia, } \\
\text { Conjunctivits, } \\
\text { Diabetes, Haemaptysis, } \\
\text { Hepato-protective } \\
\text { activity, Diarrhea, } \\
\text { Anaemia, Pharyngodynia }\end{array}$ & {$[33-38,52,56-59,63,-66]$} \\
\hline 4. & Sugars & $\begin{array}{l}\text { 1,6;2,3-Dianhydro-4-O-Acetyl-Beta-- } \\
\text { D-Gulopyranose, } \\
\text { 1,6;3,4-Dianhydro-2-O-Acetyl-. } \\
\text { Beta.-D-Galactopyranose, } \\
\text { 4H-Pyran-4-One, } \\
\text { 2,3-Dihydro-3,5-Dihydroxy-6-Methyl, } \\
\text { 2-Furan carboxy Aldehyde, } \\
\text { 5-(Hydroxymethyl), } \\
\text { d-galactose, } \\
\text { d-rhamnose, } \\
\text { l-arabinose etc }\end{array}$ & $\begin{array}{l}\text { Anaemia, Anticancer, } \\
\text { Anti-inflammatory, } \\
\text { Antioxidative, } \\
\text { Anti-ulcer, Body surface } \\
\text { infection, Catarrah, } \\
\text { Conjunctivits, Dysentery, } \\
\text { Hepato-protective } \\
\text { activity, Leprosy, Skin } \\
\text { diseases, Wound } \\
\text { treatment, Haemorrages }\end{array}$ & {$[23,42,45-48,57,59,63-67,69,72-75]$} \\
\hline 5. & Tannins & Gallic acid, Phlobatannins etc & $\begin{array}{l}\text { Antioxidative, } \\
\text { Anti-inflammatory, Skin } \\
\text { diseases, Melancholia, } \\
\text { Conjunctivits, } \\
\text { Diabetes, Haemaptysis, } \\
\text { Hepato-protective } \\
\text { activity, Catarrah, Cough, } \\
\text { Leprosy, Body surface } \\
\text { infection, Leucoderma, } \\
\text { Helminthiasis, Diarrhea, } \\
\text { Dysentery, Wound } \\
\text { treatment, Fever, } \\
\text { Anaemia }\end{array}$ & {$[33,42,45-48,57-59,63-67,69,70-75]$} \\
\hline
\end{tabular}


Table 2: (Continued)

\begin{tabular}{|c|c|c|c|c|}
\hline S. No. & $\begin{array}{l}\text { Category of } \\
\text { Phyto-chemical }\end{array}$ & Bioactive compounds & $\begin{array}{l}\text { Related medicinal } \\
\text { activities }\end{array}$ & References \\
\hline 6. & Acidic Compounds & $\begin{array}{l}\text { Acetic Acid, } \\
\text { Caprylic acid-methyl ester, } \\
\text { Lauric acid- methyl ester, } \\
\text { Myristic acid- methyl ester, } \\
\text { 2-Amino-Octadec-7-Ene-1,3-Diol Butane } \\
\text { Boronate, } \\
\text { Etc }\end{array}$ & $\begin{array}{l}\text { Antioxidative, } \\
\text { Anti-inflammatory, } \\
\text { Antipyretic, Anticancer, } \\
\text { Anti-ulcer, Skin diseases, } \\
\text { Hepato-protective } \\
\text { activity, Catarrah, Cough, } \\
\text { Pruritus, Leprosy, } \\
\text { Body surface infection, } \\
\text { Leucoderma, Fever, } \\
\text { Anaemia, Pharyngodynia }\end{array}$ & {$[43,46-49,52-59,63-67,69,72-77]$} \\
\hline 7. & Sterols & $\begin{array}{l}\text { Poriferasterol, Poriferasterolacyl Glucosides, } \\
\text { Aldobiuronic acid, etc. }\end{array}$ & $\begin{array}{l}\text { Antioxidative, } \\
\text { Anti-inflammatory, } \\
\text { Anti-ulcer, } \\
\text { Hepato-protective } \\
\text { activity, Catarrah, } \\
\text { Leucoderma, Colon } \\
\text { diseases, Dysentery, } \\
\text { Foul Ulcers Wound } \\
\text { treatment, Haemorrages, } \\
\text { Pharyngodynia }\end{array}$ & {$[19-23,42,45-48,69,72-75]$} \\
\hline 8. & Other compounds & $\begin{array}{l}\text { 2-Ethyl-3- methyl-1-butene } \\
\text { Essential oils, } \\
\text { Naphtoquinones, } \\
\text { Secondary amine, } \\
\text { Phosphine, } \\
\text { Phosphorous compounds, } \\
\text { Sulfonyl chloride, } \\
\text { Sulfone, } \\
\text { Propanoic Acid-2-Oxo, etc. }\end{array}$ & $\begin{array}{l}\text { Antioxidative, } \\
\text { Anti-inflammatory, } \\
\text { Conjunctivits, Diabetes, } \\
\text { Catarrah, Cough, Body } \\
\text { surface infection, } \\
\text { Leucoderma, Colon } \\
\text { diseases, Wound } \\
\text { treatment }\end{array}$ & {$[18-23,42-47,55,58,63-67,69,70-75]$} \\
\hline
\end{tabular}

is needed for the healing or survival of that organism. Earlier researches with different bark extract of $A$. catechu were seen to be effective treatment for wound healing $[42,43]$. Few investigations on wound healing efficiency of aqueous as well as alcoholic bark extracts of $A$. catechu in rats showed equivalent effectiveness as standard. In addition, results confirmed the presence of phyto-constituents like glycosides, carbohydrates, proteins, terpenes, saponins, phytosterols, tannins, and gums in the A. catechu bark. Both alcoholic and aqueous bark extracts of $A$. catechu are used to prepare ointment for wound healing [38,40-44]. The aqueous extract of $A$. catechu at $3-6 \% \mathrm{w} / \mathrm{w}$ has been reported to exhibit significant wound healing activity. Furthermore, a similar evaluation has been made with other varieties of Acacia stem bark. Here also some data showed that the wound healing potential is due to its bioactive components and were determined by preliminary phyto-chemical screening. In addition to this, in a number of studies, the formulation and ointment prepared from stem bark extracts in mice, rats, guinea pigs and human were seen significantly effective against microbial infected wounds [40,44-47].

Some workers have revealed the wound healing activity of combined therapy of hydroalcoholic extract of $A$. catechu and Gymnema sylvestere in albino mice and found this is occur due to free radical scavenging [48- 50]. Though, the mechanism and phyto-constitute involved in healing are not studied well. In addition to this the individual and additive impact of these phytochemicals is still not documented enough [30,51-53]. Though one study revealed that the results of TLC showed the presence of flavonoids may be the responsible factor for this. Similar results were obtained by other workers with combined treatment with Beeswax from Apis mellifera, A. catechu bark extract, the oil of
Sesamum indicum and oil of Azadirachta indica [54-57]. This combination was seen to reduce inflammation at wounded area and seen to cure wound faster than single extract treatment in mice. The same researchers also showed that the anti-inflammatory and wound healing activity occur due to prostaglandin synthesis via cyclo-oxygenase pathway in animal models [49,52,58-60]

\section{BIOACTIVE COMPONENTS OF A. CATECHU}

The term "phyto-chemical" is generally used to describe chemicals obtained from plants that may improve the health status of organisms, but are not essential nutrients [45,61-64]. There are sufficient evidence to support the health benefits of the plant in the form of roots, stems, leaves, bark, and fruits [65]. Above mentioned activities of A. catechu bark extract were observed to be associated with the quality and quantity of secondary metabolites produced by plants $[66,67]$. These seem to exert definite physiological actions through either scavenging of disease-causing free radicals or by the destruction of infectious agents from the human body [68]. Plant-based drugs are complex mixtures of bioactive compounds. The information of the potential health benefits of individual phyto-chemical is linked to the information of the health effects of a drug that contains these phytochemical $[69,70]$.

The main bioactive components isolated and studied of black catechu are flavonoids (catechin, rocatechin, epigallocatechin, epicatechin gallate, epicatechin, epigallocatechin gallate, catecutannic acid, quercitrin, quercetin, phloroglucinol, lupeol, procatechuic lupenone, procyanidin AC quercetin, quercitrin acid, etc), alkaloids (taxifolin, dihydrokaempferol, kaempferol, afzelchin gum), glycosides (poriferasterol, poriferasterol acylglucosides), tannins (gallic acid, phlobatannins), sugars (1,6;2,3-Dianhydro-4-0-Acetyl-beta-DGulopyranose, 1,6;3,4-Dianhydro-2-0-Acetyl-Beta.-D-Galactopyranose, 4H-Pyran-4-One,2,3-Dihydro-3,5-Dihydroxy-6-Methyl, 2-Furan carboxy Aldehyde,5-(Hydroxymethyl),d-galactose, d-rhamnose and L-arabinose) [16,30,44,48,64-49,71]. 
A. catechu extracts have also played a role in chemistry, with various names of chemicals as catechin, catechol, and catecholamine being derived from bark. A. catechu is already been reported for the presence of caprylic acid methyl ester in about higher concentrations. The same has also been good source of Lauric acid, methyl ester (nearly about 28\%). It has very high concentration (nearly $43 \%$ ) of 2-Ethyl-3- methyl-1-butene and nearly 11\% Myristic acid methyl ester which are known efficient bioactive compounds [72,73]. Some researchers carried out phytochemical studies of $A$. catechu and found poriferasterol, poriferasterolacyl glucosides, gallic acid, phlobatannins, d-galactose, aldobiuronic acid, d-rhamnose, and l-arabinose, etc $[18,36,73,74]$.

\section{DISCUSSION}

Today, there are more than 121 pure chemical substances extracted from about 130 species of higher, used in the modern pharmacopeias throughout the world. Out of these, 89 plants derived drugs, currently used in modern medicine, were originally discovered through the study of traditional cures and plants folk knowledge of indigenous people [27,75-78]. Medicinal plants are valuable for human ailments because of the presence of phytochemicals, which are present in the form of secondary metabolites such as alkaloids, saponin, glycosides, lactones, steroids etc. Several medicinal plants and their products are still widely used by the traditional medical practitioners for curing various diseases in their day to day practice [76-79]. Though, thousands side effects of allopathic medicines have been documented till now and much more are coming in front, so the use of herbal medicines is safer, cheaper and easily available therapeutic agents $[34,58,80]$. A. catechu based treatment is one of them.

A. catechu wild has greatimportance in ayurvedic system of medicine due to its medicinal properties [81-83]. It is well known for its therapeutic uses in dermatological, cardiovascular and respiratory diseases. Further, due to the presence of great percentage of acidic compounds the same is also used to reduce $\mathrm{pH}$ that inhibits the growth of microbial cells $[36,38,56,84]$. Catechin Obtained from the same is known antioxidant and reported to exhibit In vivo antioxidant properties against free radical attack $[67,73]$. The bark of $A$. catechu is used as a potent wound healing medicine. The extract of the bark of the same has been reported to exhibit an astringent effect in different experimental models [37,45,78,80,85]. Furthermore, it also exhibits antimicrobial property which prevents the growth of microbes on wounds. From a dental perspective, when used externally as a powder, it cures bleeding gums. It is used with great benefit internally in the form of gargle to alleviate sore throat, halitosis and dental caries. The literature has shown that it is antimicrobial against several oral pathogens, namely Streptococcus and Lactobacillus species [40-46,67,86].

During the last several decades, natural products with antimicrobial effects were investigated in order to eliminate the use of synthetic antibiotics which cause the resistance of microorganisms and can exhibit side effects to human health. Plants extract from 157 families including, $A$. catechu have been reported to be active against microorganisms [43,64,68,71,85-87]. More so, A. catechu willd has also been reported for the synthesis and secretion of various active secondary metabolites which are already known for significant medicinal values, these are phenolic compound those serve as essential oils and also have significant insecticidal and antimicrobial activities. Because of such potential the same are routinely used in some pharmaceuticals, alternative medicines and natural therapies [28,36,52-56,87-90].

\section{CONCLUSION}

In conclusion, the bark extract of $A$. catechu with different solvents are seen to be effective against pathogenic microbial strains and same has also seen to effective to cure different physiological diseases like diabetes, cancer, ulcer, anemia, inflammation, leucoderma, colon problems etc. Here, we have also found that these protective effects of the same are correlated with the presence of bioactive components which are basically produced by plant as secondary metabolites. These finding revealed that the individual as well as formulation of the bark extract of $A$. catechu with other protective compounds may be a potent and natural way to cure wounds infections than artificial harmful chemicals. With limited and guided doses the same can also used to treat abdominal infections too in case of abdominal infections. Though, further studies are needed to demonstrate the actual mechanism of action of same at the molecular level.

\section{AUTHORS CONTRIBUTION}

I, Mrs. Archana Tiwari, assistant professor, Government P.G. College Damoh, District Damoh, Madhya Pradesh, India has done the above complete review work including data search, data collection, interpretation to conclude the whole work under the guidance and supervision of Professor (Dr.) Avinash Tiwari, Head, School of studies in Microbiology, Jiwaji University, Gwalior, (M.P.) India, under whom I am pursuing my present research work as Ph.D. candidate.

\section{CONFLICTS OF INTERESTS}

No conflict.

\section{SOURCE OF FUNDING}

Nil.

\section{REFERENCES}

1. Artuso A. Drugs of Natural Origin: Economic and Policy Aspects of Discovery, Development, and Marketing. New York: Pharmaceutical Products Press; 1997.

2. Gottlieb OR. Phytochemicals: Differentiation and function. Photochemistry 1990;29:1715-24.

3. Cox PA. The ethno-botanical approach to drug discovery: Strengths and limitations. Ciba Found Symp 1994;185:25-36.

4. Jain SK, Banerjee DK, Pal DC. Medicinal plants among certain Adibasis in India. Bull Botanical Survey India 1973;13:221-3

5. Kamboj VP. Herbal medicine. Curr Sci 2000;78:35-9.

6. Kasture VS, Deshmukh VK, Chopde CT. Anxiolytic and anticonvulsive activity of $S$. grandiflora leaves in experimental animals. Phytother Res 2002; 16:455-60.

7. Eldeen IM, Elgorashi EE, Staden J. Antibacterial, anti-inflammatory, anti-cholinesterase and mutagenic effects of extracts obtained from some trees used in South African traditional medicine. J Ethnopharmacol 2005;102:457-64.

8. Marino-Bettolo GB. Present aspect of the use of plants in traditional medicine. J Ethnopharmacol 1980;2:5-7.

9. Rafi SM, Maleka BF, Naqvi S, Shaikh D. Partial purification and antibacterial studies of extracts from Eugenia jambolana Linn. and Vinca rosea Linn. Pak J Sci Ind Res 1994;37:279-81.

10. Pal SK, Shukla Y. Herbal medicine: Past present and the future. Asian Pac J Cancer Prev 2003;4:281-8.

11. Mohammed S, Khan A, Ali S. Wound healing activity of traditional herbal formulation. Inter J Chemical Sci 2009;7:639-43.

12. Naghibi F, Mosaddegh M, Motamed MM, Ghorbani A. Labiatae family in folk medicine in Iran: From ethnobotany to pharmacology. Iran J Pharm Res 2005;4:63-79.

13. Perumal PP, Sampath K, Karuppasamy PK. Studies on the bloom forming species of phytoplankton in the Vellar Estuary, Southeast coast of India. Indian J Geo Marine Sci 1999;28:400-3.

14. Reddy MB, Gowda KP, Arora AK, Study of wound healing activity of aqueous and alcoholic bark extracts of Acacia catechu on rats. J Pharm Sci 2011;1:220-5.

15. Ramli S, Harada K, Ruangrungsi N. Antioxidant, antimicrobial and cytotoxicity activities of Acacia farnesiana (L.) Willd. Leaves ethanolic extract. Pharmacogn J 2011;2:50-8.

16. Saini ML, Saini R, Roy S, Kumar A. Comparative pharmacognostical and antimicrobial studies of Acacia species (Mimosaceae). J Med Plants Res 2008;2:378-86.

17. Ray D, Sharatchandra KH, Thokchom IS. Antipyretic, antidiarrhoeal, hypoglycaemic and hepatoprotective activities of ethyl acetate extract of Acacia catechu Wild. In albino rats. Indian J Pharmacol 2006;38:408- 13 .

18. Hazra B, Sarkar R, Ghate NB, Chaudhuri D, Mandal N. Study of the 
protective effects of Katha (heartwood extract of Acacia catechu) in liver damage induced by iron overload. J Environ Pathol Toxicol Oncol 2013;32:229-40.

19. Rios JL, Recio MC, Villar A. Screening methods for natural products with anti-microbial activity: A review of the literature. J Ethnopharmacol 1988;23:127-49.

20. Divya N, Thenmozhi S, Suresh K, Selvan M. Antibacterial activity of medicinal plant against wound infected pathogens. Int J Pharm Sci Res 2014;5:4942-47.

21. Ismail S, Asad M. Immunomodulatory activity of Acacia catechu. Indian J Physiol Pharmacol 2009;53:25-33.

22. Jain R, Jain SK. Screening of in vitro cytotoxic activity of some medicinal plants used traditionally to treat cancer in Chhattisgarh state, India. Asian Pac J Trop Biomed 2011;1:S147-50.

23. Baluja S, Chanda S, Solanki A, Kachhadia N. Phytochemical studies of Acacia catechu. Indonesian J Pharm 2012;23:238-47.

24. Patel B, Rajput M, Patidar C, Khare JS, Kalidhar SB. A review on the chemistry and bioactivity of Acacia spp. J Med Aromatic Plants Sci 2005;3:51-90

25. Hassimotto NM, Genovese MI, Lajolo FM. Antioxidant activity of dietary fruits, vegetables, and commercial frozen fruit pulps. J Sci Food Agric 2005;53:2928-35.

26. Hemashree J, Thangavelu M. Anti-inflammatory action of Acacia catechu seed extract. J Adv Pharm Edu Res 2018;8:92-5.

27. Joshi S, Subedi YP, Paudel SK. Antibacterial and antifungal activity of heartwood of Acacia catechu of Nepal. J Nepal Chem Soc 2011;27:94- 9

28. Kadian R, Parle M, Sharma K. Phytopharmacology of Acacia catechu Wild: A review World. J Pharm Pharm Sci 2014;3:1380-9.

29. Patel JD, Kumar V, Bhatt SA. Antimicrobial screening and phytochemical analysis of the resin part of Acacia catechu. Pharm Biol 2009;47:34-7.

30. Patil RB, Nanjwade BK, Manv FV. Evaluation of anti inflammatory and anti arthritic effect of $S$. grandiflora bark and fruit of Terminalia chebula in rats. Int J Pharma Bio Sci 2011;5:37-46.

31. Taesotikul T, Panthong A, Kanjanapothi D, Verpoorte R, Scheffer JJ. Hippocratic screening of ethanolic extracts from two Tabernaemontana species. J Ethnopharmacol 1989;27:99-106

32. Tangeti S, Gabbita P, Ponnaluri RP, Kolasani BP. Comparative study of wound healing effect of topical Acacia catechu extract and silver sulfadiazine on excisional wound model in guinea pigs. Int J Basic Clin Pharmacol 2018;7:2347-52.

33. Valte V, Singh TI, Singh OJ, Babycha L, Aruna S. Protective effect of ethyl acetate extract of Acacia catechu in carbon tetrachloride induced hepato-toxicity. Indian Med Gaz 2012;12:159-62.

34. Yimam M, Brownell L, Hodges M, Jia Q. Analgesic effects of a standardized bioflavonoid composition from Scutellaria baicalensis and Acacia catechu. J Dietary Suppl 2012;9:155-65.

35. Parle MM, Renu K, Sharma K. Phytopharmacology of Acacia catechu willd: A review. World J Pharm Pharm Sci 2014;3:1380-9.

36. Nascimento GG, Locatelli J, Freitas PC, Silva GL. Antibacterial activity of plant extracts and phytochemicals on antibiotic-resistant bacteria. Braz J Microbiol 2000;31:247-56.

37. Alanis AJ. Resistance to antibiotics: Are we in the post-antibiotic era? Arc Med Res 2005;36:697-705.

38. Khandekar SB, Pansare TA, Satpudke SS. Phytopharmacology of Acacia catechu willd: A review. Eur J Pharm Med Res 2019;6:216-23.

39. Negi BS, Dave BP. In vitro antimicrobial activity of Acacia catechu and its phytochemical analysis. Indian J Microbiol 2010;50:369-74.

40. Griffith JA. Methicillin resistant Staphylococcus aureus in wound care. J Wound Care 1995;4:481.

41. Jenny M, Kingsbury J. Properties and prevention: A review of Pseudomonas aeruginosa. Inter J Biol Med Res 2018;2:3-18.

42. Wilbur J. Final report of the safety assessment of Acacia catechu gum, Acacia concinna fruit extract, Acacia dealbata leaf extract, Acacia dealbata leaf wax, Acacia decurrens extract, Acacia farnesiana extract, Acacia farnesiana flower wax, Acacia farnesiana gum, Acacia senegal extract, Acacia senegal gum, and Acacia senegal gum extract. Int J Toxicol 2005;24:75-118.

43. Mojab F, Kamalinejad M, Ghaderi N, Vanidipour HR. Phytochemicals screening of some species of Iranian plants. Iran J Pharm Res 2003;3:77- 82.

44. Monga J, Chauhan CS, Sharma M. Human epithelial carcinoma cytotoxicity and inhibition of DMBA/TPA induced squamous cell carcinoma in Balb/c mice by Acacia catechu heartwood. J Pharm Pharmacol 2011;63:1470-82.

45. Lakshmi T, Geetha RV, Anitha R. In vitro evaluation of antibacterial activity of Acacia catechu wild heartwood extract. Int J Pharma Biosci 2012;2:12

46. Chaudhari SK, Shalini T, Singh DP, Verma NK, Chandra V, Asha R. An overview on Acacia catechu. Inter J Res Rev Pharm Appl Sci 2012;2:342-46.

47. Evans AC. Studies on hemolytic streptococci: II. Streptococcus pyogenes. J Bacteriol 1936;31:611-24.

48. Khan MR, Kihara M, Omoloso AD. Antimicrobial activity of Cassia alata. Fitoterapia 2001;72:561-4.

49. Shen D, Wu Q, Wang M, Yang Y, Lavoie EJ, Simon JE. Determination of the predominant catechins in Acacia catech $u$ by liquid chromatography/ electrospray ionization-mass spectrome try. J Agric Food Chem 2006;54:3219-24.

50. Lawrence R, Jeyakumar E, Gupta A. Antibacterial activity of Acacia arabica (Bark) extract against selected multi drug resistant pathogenic Bacteria. Int J Curr Microbiol Appl Sci 2015;1:213-22.

51. Kiranmai M, Kazim SM, Ibrahim M. Combined wound healing activity of Gymnema sylvestre and Tagetes erecta Linn. Inter J Appl Pharm 2011;2:135-40.

52. Sanchez E, Garcia S, Heredia N. Extracts of edible and medicinal plants damage membranes of Vibrio cholera. Appl Environ Microbiol 2010;76:6888-94.

53. Alam G, Singh MP, Singh A. Wound healing potential of some medicinal plants. Int J Pharm Sci Res 2011;9:136-45.

54. Bowler PG, Duerden BI, Armstrong DG. Wound microbiology and associated approaches to wound management. Clin Microbiol Rev 2001;14:244-69.

55. Bowler PG. The anaerobic and aerobic microbiology of wounds: A review. Wounds 1998;10:170-8.

56. Chopra RN, Chopra IC, Handa KL, Kapur LD. Indigenous Drugs of India. Calcutta: U.N. Dhur and Sons Pvt. Ltd., Press; 1958.

57. Culver DH, Haley RW, White JW. The efficacy of infection surveillance and control programs in preventing nosocomial infection in the hospital. Am J Epidemiol 1985;121:181-2005.

58. Kozer M, Hamilton H, Koscova J. Types of wounds and the prevalence of bacterial contamination of wounds in the clinical practice of small animals. Folia Vet 2018;62:39-47.

59. Rahmatullah M, Hossan S, Hanif A, Roy P, Jahan R, Khan M. Ethnomedicinal applications of plants by the traditional healers of the marma tribe of naikhongchhari, Bandarban district, Bangladesh. Adv Nat Appl Sci 2009;3:392-401.

60. Sakagami Y, Kajimura K. Bactericidal activities of disinfectants against vancomycin-resistant enterococci. J Hosp Infect 2002;50:140-4.

61. Unny R, Chauhan AK, Joshi YC, Dobhal MP, Gupta RS. A review on potentiality of medicinal plants as the source of new contraceptive principles. Phytomedicine 2003;10:233-60.

62. Sulaiman CT, Gopalakrishnan VK, Balachandran I. Spectrophotometric determination of antioxidant potential of selected Acacia species. Med Plants Int J Phytomed Relat Indust 2011;3:289-92.

63. Thangavelu L, Singh AK. Preliminary phytochemical analysis and in vitro antibacterial activity of Acacia catechu willd. Bark against Streptococcus mitis, Streptococcus sanguis, and Lactobacillus acidophilus. Int J Phytomed 2011;3:579-84

64. Shukla K, Ansari MA. An Indian community based epidemiological study of wounds. J Wound Care 2004;13:323-5.

65. Ahmad R, Ali AM, Israf DA, Ismail NH, Shaari K, Lajis NH. Antioxidant, radical-scavenging, anti-inflammatory, cytotoxic and antibacterial activities of methanolic extracts of some Hedyotis species. Life Sci 2005;76:1953-64

66. Akinmoladun AC, Obuotor EM, Farombi EO. Evaluation of antioxidant and free radical scavenging capacities of some Nigerian indigenous medicinal plants. J Med Food 2010;13:444-51.

67. Ashikur RM, Hasanuzzaman M, Mofizur RM, Zahan SI, Muhuri RS. Evaluation of antibacterial activity of study of leaves of Tabernaemontana divaricata L. Int Res J Pharm 2011;2:123-7.

68. Eloff JN. Which extractant should be used for the screening and isolation of antimicrobial components from plants? J Ethnopharmacol 1998;60:1-8

69. Gajera HP, Patel SV, Golakiya BA. Antioxidant properties of some therapeutically active medicinal plants-an overview. J Med Aromatic Plant Sci 2005;27:91-100.

70. Arjmandi BH, Ormsbee LT, Elam ML, Campbell SC, Rahnama N, Payton ME, et al. A combination of Scutellaria baicalensis and Acacia catechu extracts for short-term symptomatic relief of joint discomfort associated with osteoarthritis of the knee. J Med Food 2014;17:707-13.

71. Geetha RV, Anita R, Lakshmi T. In vitro evaluation of antibacterial activity of heartwood extract of Acacia catechu Wild on enteric 
pathogens. Int J Pharm Sci 2011;9:147-9.

72. Gopinath SM, Suneetha TB, Mruganka VD, Ananda S. Evaluation of antibacterial activity of Tabernaemontana divaricata $\mathrm{L}$. Leaves against the causative organisms of Bovine mastitis. Int J Res Phytochem Pharmacol 2011;1:211-3

73. Spinella M. The importance of pharmacological synergy in psychoactive herbal medicines. Altern Med Rev 2002;7:130-7.

74. Srivastava N, Chauhan AS, Sharma B. Isolation and characterization of some phytochemicals from Indian traditional plants. Biotechnol Res Int 2012;2012:549850.

75. Sulaiman CT, Balachandran I. Total phenolics and total flavonoids in selected Indian medicinal plants. Indian J Pharm Sci 2012;74:258-60.

76. Sulaiman CT, Gopala Krishnan VK. Comparative phyto-chemical studies in selected Acacia catechu species. Inter J Pharm Pharm Sci 2012;4:458-60.

77. Asmara H, Salma R, Farah D, Shahid M. Antimicrobial activity of some plant extracts having hepatoprotective effects. J Med Plants Res 2009;3:20-3.

78. Aziz RK, Kansal R, Aronow BJ, Taylor WL, Rowe SL, Kubal M, et al. Microevolution of group a streptococci in vivo: Capturing regulatory networks engaged in socio-microbiology, niche adaptation and hypervirulence. Public Lib Sci One 2010;5:97-8.

79. Mors BW, Celia do NM, Ruppelt PB, Alvares PN. Plant natural products active against snake bite-the molecular approach. Phytochemistry 2000;55:627-42

80. Patil S, Jolly CI, Narayanan S. Free radical scavenging activity of Acacia catechu and Rotula aquatica: Implications in cancer therapy. Indian Drugs 2003;40:328-32.
81. Lampronti I, Khan MT, Bianchi N, Lambertini E, Piva R, Borgatti M, et al. Plants with antitumor properties: From biologically active molecules to drugs. Adv Phytomed 2006;2:45-63.

82. Mulligen ME, Murry-Leisure KA, Ribner BS, Standiford HC, John JF, Karvick JA, et al. Methicillin resistant Staphylococcus aureus. Am J Med 1993;94:313-28.

83. Prabhakaran S, Gothandam KM, Sivashanmugam K. Phytochemical and antimicrobial properties of Syzygium cumini an ethnomedicinal plant of Javadhu hills. Res Pharm 2011;1:22-32.

84. Chino K, Matsuo T, Iwamoto M. New 5-nucleotidase inhibitors, NPF86IA, NPF-86IB, NPF-86IIA, and NPF-86IIB from Areca catechu antitumor effects. Planta Med 1988;54:419-22.

85. Chopra I, Hodgson J, Metcalf B, Poste G. The search for antimicrobial agents effective against Bacteria resistant to multiple antibiotics. Antimicrob Agents Chemother 1997;41:497-503.

86. Yoganarasimhan SN. Medicinal plant of India (Karnataka). Bangalore Indian J Tradit Knowl 2010;9:90-5.

87. Thombre R, Jagtap R, Patil N. Evaluation of phytoconstituents, antibacterial, antioxidant and cytotoxicity activity of Vitex negundo L. and Tabernaemontana divaricata L. Int J Pharm Biol Sci 2013;4:389-96.

88. Upadhyay OP, Singh RH, Dutta SK. Studies on anti-diabetic medicinal plants used in Indian folklore. Sachitra Ayurveda 1996;48:949-55.

89. Li XC, Liu C, Yang LX, Chen RY. Phenolic compounds from the aqueous extract of Acacia catechu. J Asian Natl Prod Res 2011; 13:826- 30 .

90. Patel J, Vipin S. Antimicrobial screening and phytochemical analysis of the resin part of Acacia catechu pharmaceutical. Biol J 2009;47:34-7. 